\title{
The role of Community Mental Health in a new architecture of World psychiatry and Global Mental Health
}

\author{
Renato D. Alarcón-Guzmán 1,2 Humberto Castillo-Martell2,3
}

Department of Psychiatry and Psychology, Mayo Clinic School of Medicine, Rochester, MN, USA.

2 Universidad Peruana Cayetano Heredia, Lima, Perú

3 Instituto Nacional de Salud Mental Honorio Delgado-Hideyo Noguchi.

\section{Correspondence:}

Renato D. Alarcón, MD, MPH

1 Lakeside Dr. Apt. 1602

Oakland, CA, 94612, USA.

Phone: (507) 254 - 645]

Email: Alarcon.Renato@mayo.edu

Received: 17 August 2020

Accepted: 16 September 2020

\section{Citation:}

Alarcón-Guzmán, R. D., \& Castillo-Martell, H. (2020). The role of Community Mental Health in a new architecture of World psychiatry and Global Mental Health. Salud Mental, 43(5), 235-240

DOI: $10.17711 /$ SM.0185-3325.2020.032

\begin{abstract}
Introduction. The influx of new knowledge and scientific contributions into contemporary world psychiatry has counted on a vigorous dissemination through technology-inspired means. This process has led to the realities of Global Mental Health (GMH) inspired by "a new epistemology" of mostly positivistic roots. Objective. To explore the basis of these realities and the resulting homogenization attempts of psychiatry as a medical, clinical, and research discipline. Discussion and conclusion. The need for "a new architecture" of contemporary psychiatry is discussed as a reflection of a correct epistemological exercise and a renewed pact between professionals and communities, materialized in and enriched by the re-emerging Community Mental Health $(\mathrm{CMH})$ movement. The essential bases of the movement are presented, and its mutually collaborative, multidisciplinary, integrated, and realistic nature, as reflected in national efforts like Peru's in Latin America, is described.
\end{abstract}

Keywords: Global Mental Health, Community Mental Health, epistemology, epidemiology, mental health strategies.

\section{RESUMEN}

Introducción. El flujo de nuevos conocimientos y contribuciones científicas surgido en la psiquiatría mundial contemporánea ha contado con una vigorosa diseminación mediada por recursos tecnológicos. Este proceso ha conducido a las realidades de la Salud Mental Global (SMG) inspiradas por una "nueva epistemología" de raíces fundamentalmente positivistas. Objetivo. Explorar las bases de esta nueva realidad y los resultantes intentos de homogenización de la psiquiatría como disciplina médica, clínica y de investigación. Discusión y conclusión. Se discute la necesidad de "una nueva arquitectura" de la psiquiatría contemporánea como reflejo de un correcto ejercicio epistemológico y de un pacto renovado entre profesionales y comunidades que se han materializado y enriquecido por el reemergente movimiento de la Salud Mental Comunitaria (SMC). Se presentan las bases esenciales del movimiento y su naturaleza de mutua colaboración multidisciplinaria, integrada y realista, reflejada en esfuerzos nacionales como es el caso del Perú en América Latina.

Palabras clave: Salud Mental Global, Salud Mental Comunitaria, epistemología, epidemiología, estrategias de salud mental. 


\section{INTRODUCTION}

In the last few decades, the concept and practical implications of Community Mental Health $(\mathrm{CMH})$ have experienced a notorious re-emergence in clinical and research areas of world psychiatry. A movement inspired by the reform of health systems in Europe and America dating back to the 1960s (Barton, 1966; Breakey, 1996; Desviat, 2011), CMH makes the community a well-defined protagonist of the various aspects and processes of mental health care, redefining its principles and strategies, particularly in multi-cultural countries, and facing a globalizing context in terms of daily life, economy, and mental health (Fernando, 2014). As a result, and particularly during the last two decades, world psychiatry has incorporated the notion of Global Mental Health $(\mathrm{GBH})$ to reflect what many consider strong connections between local-regional and international-universal perspectives (Bemme \& D'souza, 2014), emphasizing a reciprocal exchange of principles, practices, and impacts, and incorporating strong contributions from the social sciences field (Kohrt \& Mendenhall, 2015).

The expansion and globalization of mental health processes do not have only the reduction of mental illnesses and emotional suffering as main motivating factors: such a notion would provide only a naïve or simplistic public health perspective (Campbell \& Burgess, 2012). Concurrent objectives, interests, and possibilities are much needed to move, evolve, reinforce, and transform the value of mental health as one of the main sources of a healthy human capital above and beyond its mere economy-activating potential (Patel, 2014). From the same perspective, however, a globalizing neoliberal economic model generates inequities that reduce its viability and demand adjustments through effective social policies which, in turn, could also make possible a highly, more effective world mental health profile (Desjarlais, Eisenberg, Good, \& Kleinman, 1995; Mills, 2014).

In this article, comprehensive and, at the same time, critical reflections on GMH are formulated, on the basis of $\mathrm{CMH}$ experiences from several Latin American countries, particularly Peru. This objective has been consistently inspired by the research, insights, and contributions of Duncan Pedersen, an Argentinian physician, anthropologist, and Professor of Psychiatry at McGill University in Montreal, Canada (Alarcón-Guzmán, 2017). In Pedersen's (2015a, p. 613) own words:

"Our most serious contemporary problems -mental health included-are an intrinsic part of the globalization process: the world financial crisis, climate change, the degradation of echo-systems, poverty, and the increase in social inequities, migration, and forced displacement of populations, conflicts, and war are fundamental elements inherent to the current civilization at a global scale. It is the nature and the global outreach of this group of contempo- rary problems what represents the primary causal network leading to the social building (and apparent scaling up) of mental disorders, a main feature of today's global mental health research agenda."

\section{A NEW EPISTEMOLOGY}

Along the 20th Century, positivistic epistemology has been successful in the macro-ambits of physics, chemistry, and biology, but has faced strong limitations in its attempts to understand and intervene in more complex dimensions such as physical reality (Prigogine \& Stengers, 1997; Dreher, 2003). Nevertheless, it has reached the field of psychosocial realities, and is even considered by many as the basic theoretical component of modern psychiatry and, implicitly, of Global Mental Health, by centering its objectives on just empirically demonstrable dimensions -those perceivable by sensorial organs-, contemporary epistemology sets aside, shortens up, constricts, or devalues multiple other approaches for the understanding and management of mental illnesses and their victims' concomitant suffering (Summerfield, 2008). Authors like Maturana and Varela (2011a) substantially question the positivistic concepts of objectivity and "neutrality of knowledge" by recognizing that humans perceive the world according to their peculiar ways of being and living (the "biology of knowledge"). In this sense, what we, human beings, perceive as objective reality would not be more than sensations or perceptions (information) about a broad consensus of particular experiences generated by our diverse levels of co-existence (Maturana \& Varela, 2011b).

In turn, constructivist theories (Bruner, 1986; Fernández Zubieta, 2009) allow for the understanding of diseases, not as objective realities that occur previously and outside of the observing subjects but, rather, as constructs shaped up in the mind of those observers, as a product of others' problematic experiences in some ambits of their lives (Caponi, 2010). Human beings problematize, i.e., become uncomfortable, and health professionals attempt to change such negative aspects of the process of living (defined as objects of analysis and intervention) by reaching a consensus, regarded as truly objective, about the experiences of those "others." From such a perspective, any negative self-perception (be that from dental caries to atrial arrythmias) would reflect a modality or a moment in the complex interactions of the individual, but would only be considered a disease when the person problematizes it, when he/she has the expectation of being/feeling something different, and searches for a potential intervention that would change it (Testa, 1993; Fosnot, 2005).

Free from the ties of positivism and relying on the epistemological openings of constructivism, it is feasible to legitimize a creative way to objectify mental illness through 
the preponderance of form over content (Berrios, 2015), that is, of the organization over the structure, reducing the relevance of sensorial observation as maximal evidence of objectivity. Overcoming the predominance of scientific positivism in the mental health field assists also in weakening other processes placed at the same epistemological level, that is, other ways of thinking, understanding, explaining, and intervening in mental processes, particularly psychoanalysis and systemic psychologies, whose objectivity has been continuously questioned (Solms \& Turnbull, 2004; Kernberg, 2006; García de Frutos, 2011). This approach encompasses mental, cognitive, emotional, neurophysiological, biochemical, and even spiritual levels of knowledge, in laudable comprehensiveness-inspired efforts (Meyer \& McLaughlin, 1998).

The above rationale has brought psychiatry closer to the rest of medicine and other biological sciences by proposing that all diseases, even those detected by magnetic resonance, echography, or other technological tools, are social constructs (Rosen, 1968; Meyer \& McLaughlin, 1998). Psychiatrists, other physicians, and all scientists "build" diseases, their objects, methods, and measuring instruments and, as if it all were still insufficient, their own criteria of truthfulness and validity: non-existing objects become real (Kandel, 2005; Castillo-Martell, 2014). Our own body has been building itself through the experience of living, a process through which we have also been building norms and signals to live more and better. The problematization, i.e., the expectation of situational changes, and the existence of some cultural or biological mechanisms with disordering capabilities, make up a disease. This would generate a continuous process of social production that, following a given course, may eventually lead to the discontinuation of some diseases and the appearance of others (Granda, 1991; Alarcón, 2013).

It is quite possible, however, that a "psychiatry of diversity," as that sketched here, may result more complex than a "universal psychiatry." While such could be the case, it should not be forgotten that the cost of homogenizing existing heterogeneities can be even higher, particularly for those who are socially (or economically) distant from the hegemonic cultural centers. These considerations must be part of any attempt to reformulate the relationship between contemporary psychiatry and global mental health.

\section{A NEW PROFESSIONALS- COMMUNITY PACT}

It is, therefore, crucial to work on broadening the social projection of psychiatry through an epistemological reform that would embody the will to understand (using this word in both its cognitive and affective senses) and foster a major and authentic approximation to people, a respectful and prudent assumption of diversities, a determined effort to integrate different perspectives and approaches, and to learn from our patients (de Heras, 2012; Alarcón, 2013; 2016). At the same time, we should be aware that in a tenacious seek to be right, we may be destroying other legitimate ways of thinking, i.e., commit an epistemicide (Dowbiggin, 2011; de Sousa Santos, 2018). Ours is the noble and complex task of rescuing and fortifying trust between and among different persons, communities, and cultures. We must remember that trust emerges through the recognition of "the other" as a legitimate and intelligent being just because he/she exists and is in his/her circumstance, and as a product of his/her own experiences (Laín Entralgo, 1988). Moreover, we must cut out individualization and competitiveness to allow a truly constructive collaboration. We must distrust images and simplifications. Psychiatry's homogenization is impeding us to learn from our patients and, by teaching a simplified version of it, we may be generating growing levels of ignorance about the whole of life (Mariátegui, 2008; Delgado, 1992).

Reality is a very complex entity: many notions about it may be considered as not too clear, but a collaborative work in favor of an ecology of psychiatric, psychopathological, and psychotherapeutic varieties of knowledge (Lancet Global Mental Health Group et al., 2007; de Sousa Santos, 2010) may show them to be more or less efficacious in different conditions. There is not one being, there is $a$ being with, to, for, or against others. Acknowledgment occurs before knowledge. Diversity is something for us to celebrate, not to be resigned to.

In this complex scenario, full of discourses pretending to be totally reasonable, it is important, each time, to build truth as it flows from the patient (Valenzuela-Espinoza, 2012). We have to resist considering him/her just as an object of diagnosis and treatment and, rather, build a collaborative pact in which we will never assume that he/ she does not have or has lost the capacity to reason. On the contrary, we must accept that his/her emotions, reasoning or discourse reflect efforts of a constructive adaptation to his/her history and circumstances. Somehow, we must understand the symptom(s) as the patient's discursive form of resistance to the maneuvers of known and unknown powers (Huertas, 2006; Berrios, 2015). Their study implies the use of a "complex historiographic proposal" covering natural and socio-cultural factors, as well as the impact and transformations of institutions and anings of theoretical concepts (Lázaro \& Stucchi, 2019).

We must pursue an open, inclusive way of knowing, understanding the clinical events we find, and face them as a reality in the process of being (Zemelman, 2011), rather than as a thorough, uncontestable one. Interviewing a patient must be an active, not a passive process of knowing. To know is to act, to change the way of knowing is to change relational and power-relations styles, and, with them, ways of living, and community life itself. Such is the essence of 
de Souza Santos' (2010) statement: "In order to have social justice, there must be, first, epistemological justice." To be conscious about these facts is relevant for the advancement of a psychiatry aimed at a genuine liberation of individuals and groups that seek its guidance and care.

\section{COMMUNITY MENTAL HEALTH AS A STRATEGY IN LATIN AMERICA}

The CMH approach constitutes a solid strategy to bring globally accepted notions of public mental health to local and national settings, articulating them in spaces of culturally original knowledge, reconfiguration of power, and trust-building initiatives (Kirmayer \& Pedersen, 2014; Castillo-Martell \& Cutipé-Cárdenas, 2019). The cultural recognition of social and family-based traditions, beliefs, and practices adds and interacts with established clinical concepts and with integrated, multi-disciplinary teams to make possible a positive dialogue between communities, general health institutions, and mental health services. A systematic inter-professional dialogue, the acceptance of strong interactive socio-cultural variables, and an objective clinical acumen will round up the process (Saraceno \& Dua, 2009; Alarcón, 2016).

The above propositions are becoming a reality in some world regions such as the Latin American subcontinent. In Peru, projects and programs of $\mathrm{CMH}$, many of them following ideas or initiatives inspired, suggested and pursued by Duncan Pedersen for more than 30 years, have started to materialize (Pedersen, 2015a; 2015b). For instance, the Mental Health and Human Development project, jointly elaborated by McGill University and Lima's Universidad Peruana Cayetano Heredia, led to the formation of critical nuclei of researchers and professionals actively involved in the $\mathrm{CMH}$ field. A series of studies and interventions in high-Andean communities of the Ayacucho region (Pedersen, Gamarra, Planas, \& Errázuriz, 2001), strengthened the articulation of local knowledge with Western notions, making possible a cogent questioning of details of categorical diagnoses like Post-traumatic Stress Disorder (Toyama et al., 2017). Similarly, studies of interventions about stigma as a construct reflecting conceptual conflicts and social battles are enriched ongoing debates.

In the last six years, these accomplishments and innovations have been consolidating and moving up in such a way that now the country is conducting a community mental health-inspired reform (World Bank Group, 2018; Castillo-Martell \& Cutipé-Cárdenas, 2019). This process, reinforced by a recently approved integral Mental Health Law (El Peruano, 2019), is making possible a more effective access to evaluation, service, studies, and research about the alleviation of mental/emotional suffering in large population sectors of the Peruvian territory. It is a collaborative, participative, and interdisciplinary approach already imple- mented through the creation of more than 150 community mental health centers across the country, and a goal of near 1000 more is still to be reached.

\section{DISCUSSION AND CONCLUSION}

The epistemological postulates of a psychiatry becoming hegemonic at the roots of the current global mental health realities run the risk of being extremely simple for the scenarios in which our discipline operates. Such approach not only reduces its potential effectiveness in the management of the mental and relational complexities psychiatry deals with, but also risks mutilating something that it does not entirely understand. It may destroy knowledge, it may commit, let it be said once again, epistemicide. Moreover, this simplification is not only a conceptual issue: it may have, in fact, an elective connection or specific affinity with mutually feeding features of authoritarian politics, neoliberal economy, and positivistic epistemology.

Globalization is the topic of heated debates in many areas and from a variety of perspectives making it a mixed bag of promising achievements and dangerous uncertainties. The possibilities of a truly balanced universalization conveying hope and a determination to create order, opportunities to improve, and genuine progress via cogent exchanges, may confront, at the other extreme, undesired and unexpected decimation of initiatives, divisiveness, or undecisive leaderships (Alarcón-Guzmán, 2017). Moreover, globalization may engender a counter-effect of hyper-localization with implications of separation, segregation, and social marginalization.

In the mental health field, globalization expands the vision of comparative epidemiology and clinical approaches but may tend to minimize the social determinants by means of false generalizations, material, financial and human resource limitations, risks of national and international bureaucratization, and different levels of fortitude and political will in diverse countries and regions (Mehta, Croudace, \& Davies, 2015).

The role of the $\mathrm{CMH}$ movement in the construction of a "new architecture" for world psychiatry and its global mental health outreach is and will be decisive. To fully realize it in the natural laboratories of everyday life across the world, a multi-focal perspective will be indispensable. It is not only an increased number of human resources but also an innovative task-sharing, the involvement of non-specialist providers in the context of integrative or comprehensive care and shared decision-making, team-based approaches (Brunk, 2013; Unützer, 2014). The need of dialogues to avoid clichés or confusions in theory and practice, the adaptability of norms and practical measures, and the respect for differences of opinion or action policies are also very relevant components (Katontoka, 2012). 
Last but not least, the conceptual and practical value of GMH will depend on an intelligent use of the resources of cultural psychiatry understood both, as a repository of epistemological wisdom, and an agile and efficient instrument of inquiry into and solution of psychopathological conundrums (Alarcón, 2013; 2016; Buekens, Keusch, Belizan, \& Bhutta, 2004). The last report from Napier et al. (2014) accepted the primarily social nature of these efforts to distinguish between "the objectivity of science and the subjectivity of culture."

Mental Health reform processes, based on a genuinely integrated community approach, like those currently taking place in several Latin American countries like Peru, provide an opportunity to advance towards a genuinely conceived Global Mental Health, whose architecture will require the harmonious combination of different perspectives and tools. By filling in the existing big service gaps, and providing large segments of the world population with access to modern medical technologies and standardized therapies, this process would also allow for the articulation of diverse sources of knowledge, and the building of a psychiatry duly open to the life complexities of all human beings.

\section{Funding}

None.

\section{Conflicts of interest}

The authors declare they have no conflicts of interest.

\section{REFERENCES}

Alarcón, R. D. (Ed.) (2013) Cultural Psychiatry. Basel, Switzerland: Karger. Alarcón, R. D. (2016). Global Mental health and Cultural Psychiatry: Links, overlaps and distinctions. In Villaseñor-Bayardo, S. J., Alarcón, R. D., Rohlof, H., \& Aceves-Pulido M. P., (Eds.). Global Challenges \& Cultural Psychiatry. Guadalajara, México: Universidad de Guadalahara.

Alarcón-Guzmán, R. D. (2017). Duncan Pedersen y el estudio integral de la Salud Mental Global. Revista de Neuro-Psiquiatría, 80(1), 72-74. doi: 10.20453/rnp.v80i1.3061

Barton, W. E. (1966). Trends in community mental health programs. Psychiatric Services, 17(9), 253-258. doi: 10.1176/ps.17.9.253

Bemme, D., \& D'souza, N. A. (2014). Global mental health and its discontents: An inquiry into the making ofglobalandlocalscale. Transcultural Psychiatry, 51(6), 850-874. doi: 10.1177/1363461514539830

Berrios, G. E. (2015). History and epistemology of psychopathology. In Kendler, K. S., \& Parnas, J. (Eds.). Philosophical issues in psychiatry III: The nature and sources of historical change. Oxford, USA: Oxford University Press. doi: 10.1093/med/9780198725978.001.0001

Breakey, W. R. (Ed.). (1996). Integrated Mental health Services: Modern Community Psychiatry. New York, NY: Oxford University Press.

Bruner, J. (1986). Actual minds, possible worlds. Cambridge, MA: Harvard University Press.

Brunk, D. (2013). Integrative care is the future of psychiatric care. Clinical Psychiatry News. Retrieved from https://www.mdedge.com/psychiatry/article/57959/ health-policy/integrative-care-future-psychiatric-care

Buekens, P., Keusch, G., Belizan, J., \& Bhutta, Z. A. (2004). Evidence-based Global Health. JAMA, 291(21), 2639-2641. doi: 10.1001/jama.291.21.2639

Campbell, C., \& Burgess, R. (2012). The role of communities in advancing the goals of the Movement for Global Mental Health. Transcultural Psychiatry, 49(3-4), 379-395. doi: $10.1177 / 1363461512454643$
Caponi, S. (2010). Georges Canguilhem: del cuerpo subjetivo a la localización cerebral. Salud Colectiva, 6(2), 149-161. doi: 10.18294/sc.2010.363

Castillo-Martell, H. (2014). Horizontes epistemológicos de la psiquiatría: objetivando la subjetividad. Revista de Neuropsiquiatría, 77(2), 78-85.

Castillo-Martell, H., \& Cutipé-Cárdenas, Y. (2019). Implementación, resultados iniciales y sostenibilidad de la reforma de servicios de salud mental en el Perú, 2013-2018. Revista Peruana de Medicina Experimental y Salud Pública, 36(2), 326-333. doi: 10.17843/rpmesp.2019.362.4624

de Sousa Santos, B. (2010). Descolonizar el saber, reinventar el poder. Montevideo, Uruguay: Ediciones Trilce.

de Sousa Santos, B. (2018). Epistemología del Sur: un pensamiento alternativo de alternativas políticas. Geograficando, 14(1), 4-8. doi: $10.24215 / 2346898 \mathrm{Xe} 032$

Delgado, H. (1992). El médico, la medicina y el alma (3rd. Ed.). Lima, Perú: Fondo Editorial Universidad Peruana Cayetano Heredia.

Desjarlais, R., Eisenberg, L., Good, B., \& Kleinman, A. (1995). World Mental Health. Problems and priorities in Low-Income countries. New York, NY: Oxford University Press.

Desviat, M. (2011). Panorama internacional de la reforma psiquiátrica. Ciência \& Saúde Coletiva, 16(12), 4615-4622. doi: 10.1590/S1413-81232011001300010

Dowbiggin, I. (2011). The quest for mental health. A tale of science, medicine, scandal, sorrow, and mass society. Cambridge, UK: Cambridge University Press.

Dreher, H. (2003). Mind-Body unity. A new vision for Mind-Body Science and Medicine. Baltimore, MD: The Johns Hopkins University Press.

El Peruano (Diario Oficial) (2019). Ley 30947 de Salud Mental. Lima, Perú. Retrieved from https://busquedas.elperuano.pe/normaslegales/ley-de-saludmental-ley-n-30947-1772004-1/

Fernando, S. (2014). Mental health worldwide: Culture, globalization and development. Basingstoke, UK: Palgrave Macmillan.

Fernández Zubieta, A. (2009). El constructivismo social en la ciencia y la tecnología: Las consecuencias no previstas de la ambivalencia epistemológica. Arbor Ciencia, Pensamiento y Cultura, 185(738), 689-703. doi: 10.3989/ arbor.2009.738n1046

Fosnot, C. T. (Ed.). (2005). Constructivism: Theory, perspectives and practice. (2nd. Ed.). New York, NY: Teachers College Press.

García de Frutos, H. (2011). Neurociencias y psicoanálisis: consideraciones epistemológicas para una dialéctica posible sobre la subjetividad. Revista de la Asociación Española de Neuropsiquiatría, 31(4), 661-678. doi: 10.4321/s021157352011000400005

Granda, E. (1991). Avances conceptuales y metodológicos sobre condiciones de vida y salud. Caracas, Venezuela: Universidad Central de Venezuela, Rectoría.

de Heras, L. (2012). Entrevista a Humberto Maturana, premio Nacional de Ciencias. Revista Ciencia Joven, 1(1), 2-6.

Huertas, R. (2006). Foucault, treinta años después. A propósito de El poder psiquiátrico. Asclepio, 58(2), 267-276. doi: 10.3989/asclepio.2006.v58.i2.17

Kandel, E. R. (2005). A new intellectual framework for Psychiatry. In Psychiatry, Psychoanalysis and the new Biology of Mind. Arlington, VA: American Psychiatric Publishing, Inc.

Katontoka, S. (2012). Consumer recovery: A call for partnership between researchers and consumers. World Psychiatry, 11(3) 170-171. doi: 10.1002/j.20515545.2012.tb00126.x

Kernberg, O. F. (2006). Psychoanalytic controversies: The pressing need to increase research in and on psychoanalysis. International Journal of Psychoanalysis, 87(4), 919-936. doi: 10.1516/46N7-ULAM-DQKR-VGRT

Kirmayer, L. J., \& Pedersen, D. (2014). Toward a new architecture for global mental health. Transcultural Psychiatry, 51(6), 759-776. doi: $10.1177 / 1363461514557202$

Kohrt, B. A., \& Mendenhall, E. (2015). Global Mental health. Anthropological Perspectives. Walnut Creek, CA: Left Coast Press.

Laín Entralgo, P. (1988). Teoría y realidad del otro (1st. reimpr.) Madrid, España: Alianza Universidad.

Lancet Global Mental Health Group; Chisholm, D., Flisher, A. J., Lund, C., Patel, V., Saxena, S., ... Tomlinson, M. (2007). Scale up services for mental disorders: A call for action. Lancet, 370(9594), 1241-1252. doi: 10.1016/S01406736(07)61242-2 
Lázaro, J., \& Stucchi, S. (2019) Historia de las ideas psiquiátricas. In Alarcón, R. D., Chaskel, R., \& Berlanga, C. (Eds.). Psiquiatría (4a. Ed.). Lima, Perú: Fondo Editorial Universidad Peruana Cayetano Heredia.

Mariátegui, J. (2008). La Medicina como ciencia social. Revista de Neuro-Psiquiatría, 71(1-4), 3-7.

Maturana, H., \& Varela, F. (2011a). Preface to the second edition of "De Máquinas y Seres Vivos-Autopoiesis: La organización de lo vivo". Systems Research and Behavioral Science, 28(6), 583-600. doi: 10.1002/sres.1124

Maturana, H., \& Varela, F. (2011b). El árbol del conocimiento: las bases biológicas del entendimiento humano. Santiago de Chile: Editorial Universitaria.

Mehta, N., Croudace, T., \& Davies, D. S. C. (2015). Public mental health: evidencebased priorities. The Lancet, 385(9976), 1472-1475. doi: 10.1016/S01406736(14)61400-8

Meyer, R. E., \& McLaughlin, C. J. (1998). Between mind, brain, and managed care. The now and future world of Academic Psychiatry. Washington, DC: American Psychiatric Press, Inc.

Mills, C. (2014). Decolonizing global mental health: The psychiatrization of the majority world. London, UK: Routledge.

Napier, A. D., Ancarno, C., Butler, B., Calabrese, J., Chater, A., Chatterjee, H., ... Woolf, K. (2014). Culture and health. The Lancet, 384(9954), 1607-1639. doi: 10.1016/S0140-6736(14)61603-2

Patel, V. (2014). Why mental health matters to global health. Transcultural Psychiatry, 51(6), 777-789. doi: 10.1177/1363461514524473

Pedersen, D. (2015a). Reflections social inequalities and mental health outcomes: Toward a new architecture for global mental health. In Kirmayer, L. J., Lemelson, R., \& Cummings, C. A. (Eds.). Re-Visioning Psychiatry. Cultural Phenomenology, Critical Neuroscience and Global Mental Health. Cambridge, UK: Cambridge University Press.

Pedersen, D. (2015b). Rethinking Trauma as a Global Challenge. In SchoulerOcak, M. (Ed.). Trauma and Migration: Cultural factors in the diagnosis and treatment of traumatised immigrants. Bern, Switzerland: Springer International Publishing.

Pedersen, D., Gamarra, J., Planas, M. E., \& Errázuriz, C. (2001). Violencia política y salud en las comunidades alto-andinas de Ayacucho, Perú. Retrieved from http://www.psicosocial.net/historico/index.php?option=com docman\&view=download\&alias $=670$-violencia-politica-y-salud-en-las- comunidades-alto-andinas-de-ayacucho-peru\&category slug=pueblosoriginarios\&Itemid $=100225$

Prigogine, I., \& Stengers, I. (1997). The end of certainty: Time, chaos, and the new laws of nature. New York, NY: Free Press.

Rosen, G. (1968). Madness in Society. Chapters in the historical sociology of mental illness. Chicago, IL: The University of Chicago Press.

Saraceno, B., \& Dua, T. (2009). Global mental health: the role of psychiatry. European Archives of Psychiatry and Clinical Neuroscience, 259(2), S109-117. doi: 10.1007/s00406-009-0059-4

Solms, M., \& Turnbull, O. (2004). El cerebro y el mundo interior: Una introducción a la neurociencia de la experiencia subjetiva. México, D.F.: Fondo de Cultura Económica.

Summerfield, D. (2008). How scientifically valid is the knowledge base of global mental health? British Medical Journal, 336(7651), 992-994. doi: 10.1136/ bmj.39513.441030.AD

Testa, M. (1993). Pensar en Salud. Buenos Aires, Argentina: Lugar Editorial.

Toyama, M., Castillo, H., Galea, J. T., Brandt, L. R., Mendoza, M., Herrera, V., ... Miranda, J. J. (2017). Peruvian Mental Health Reform: A Framework for Scaling-up Mental Health Services. International Journal of Health Policy and Management, 6(9), 501-508. doi: 10.15171/ijhpm.2017.07

Unützer, J. (2014). Which flavor of Integrated Care?. Psychiatric News, 49, 20. doi: 10.1176/appi.pn.2014.10b25

Valenzuela-Espinoza, I. (2012). Complejidad, globalización y teoría social. Polis, Revista Latinoamericana, 11(31), 499-520. doi: 10.4067/S0718 65682012000100026

World Bank Group. (2018). Healing minds, changing lives: a movement for community-based mental health care in Peru - delivery innovations in a lowincome community, 2013-2016. Global Mental Health Initiative. Washington, D.C.: World Bank Group. Retrieved from https://documents.worldbank.org/en/ publication/documents-reports/documentdetail/407921523031016762/healingminds-changing-lives-a-movement-for-community-based-mental-health-carein-peru-delivery-innovations-in-a-low-income-community-2013-2016

Zemelman, H. (2011). Implicaciones epistémicas del pensar histórico desde la perspectiva del sujeto. Desacatos Revista de Ciencias Sociales, 37, 33-38. doi: $10.29340 / 37.286$ 